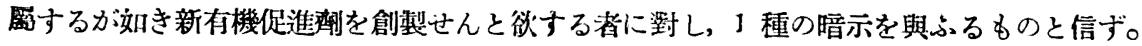

摘

要

（1）一般有機酸がゴムゾルに如何なる行䉆を及ぼすべき乎を確むる䉆に，酪酸，纐草酸，プロピオン酸， モノクロル酳酸, ブロム醋酸, $p$-ブロム安息香酸及 0 -沃素安息香酸等の各少量を稀薄ゴムベンゾール溶液に 添加して粘度紸化を時間的に測定し，各有機酸涯加の場合に於けるゴムゾルの時間粘度曲線を作成したり。

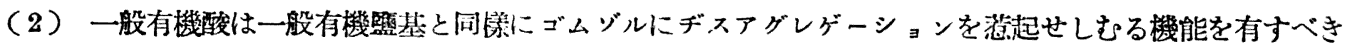
を，供試有機酸涯加に依るゴム溶液の粘度變化樣式を根㨜として推定せり。

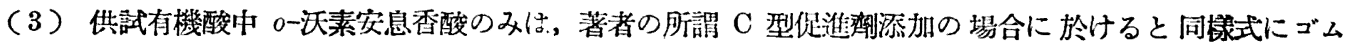
ゾルの粘度を減少せしむるを觀察し，該酸がゴムにデポリメリゼーションを落起せしむるは其構造中に沃素を

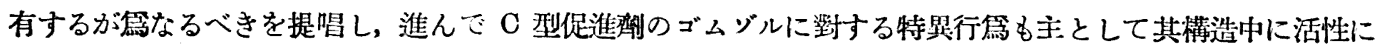
富める根基を含むに基因すべきものなるを指摘したり。

（要知時計電機株式會洞）（昭和 9 作 1 月 6 日受理）

\title{
航空發動蟣用燃料としての揮發油,ベンリ゙ール, 酒精混合物の混合性に就
}

荒木 鶴雄 - 中村 正素

ガソリン,アルコール混合然料は現今自動車用然料として或程度使用せられるが、航空登動機用としては㸴 究的に使用せられて居るが末だ充分な检討が行はれて居ない樣である。アルコールは低發熱量のるのであるが 氣化の潜熱が高い䉆に容積效果が良く從て出馬力に影響を與へないし， ヌアンチノっキングの性資はヘンンゾー ル以上とせられるために充分に使用の目的を達し得るものと考へられるが，無水酒精に非ざる限り任意の混合 をする事が出來ず，工業用酒精ではその混合範園が限定せられ低温度に於て分離する事や不完全燃燒物は明に

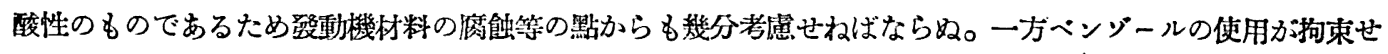
られる樣な事か起る場合をも考虑してアルコール混合然料に就て少しでも政究を進めておく必要があると考へ て研究に着手し始めたのであつて，こっには混合性に就て行つた實驗結果を報告する。

ガソッンとェチルアルコールとの相互溶解度の測定に關する交献としては次の如きすのがある。郎ち Os・ borne, N. S. 氏等 (Bull. Rur. Standards, 1913, 9, No.3, 344) はケロシンとェチルアルコールの溶解度を测 定し Ormandy Craven 氏 (Proc. Inst. Automotive Engre, 19:4, 18，(1)，313）は6種のガソッンに對する エチルアルコールの溶解度を測定し Hubendick 氏 (Trans. Fuel Conf., World Pouer Conf., Lındon, 1928, 3, 724 (1929)) も亦ガソリンに對するエチルアルュールの溶解度を測定した。Nicolardot 氏(Technique automobile, 1921, No. 115, 4th Trimestre, p. 116)は芳香族其他の物質を加へた時の溶解度を湘定し, Sparrow 氏 (Natl. Advisory Comm. Aeronaut., Tech. Kept., 1925, 232)は航空掩發油に關する测定を行つた。又 Oscar C. Bridgeman 及 Dale Querfeld 氏 (Ind. Eng. Chem., 1933, 25, 523) は含水量既知のエチルアルュ ールに 23 種のガソリンを加へ此等の溶液を冷却して 2 相となる温度郎ち臨界溶解溫度を测定した。 


\section{實 驗 の 部}

1. 試 料 本實驗に使用したガソリン,アルコール及ベンゾールの性狀は下の犃きものである。

揮發油：航空 3 號掩發油 (日本石油株式會社製蝙蝠印)，アルコール：然料用變性アルコール(明治製糖株式 會社製), ベンゾール：八幡製鐵所製大每印

A. 揮 發 油

（1）比重 $d_{4}^{15}=0.7440$ (有栓のピクノメーターを用ひ $15^{\circ} \mathrm{C}$ に於て測定した)

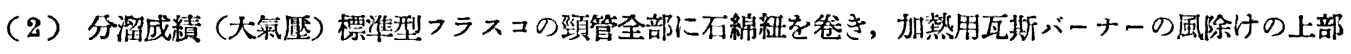

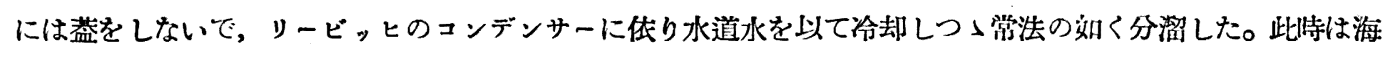
軍替格型の冷却器がなかつたのでリービ,ヒのコンデンサーを使用したのであるが其後规格型の冷却器を用ひ

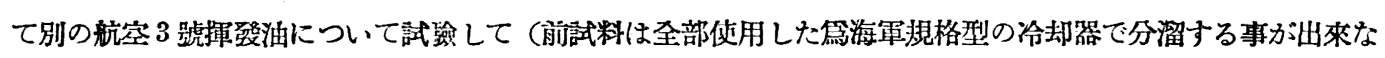
かつた) リービッヒのコンデンサーを用ひた場合と比較試驗したところ初溜㫮に約 $2^{\circ} \mathrm{C}$ の差があつたのみで他 は殆ど一致した結果を得たのでリービッヒのコンデンサーに依る結果を下に記すことにする。

\begin{tabular}{|c|c|c|}
\hline 溜 罝度 $^{\circ} \mathrm{C}$ & $\begin{array}{l}\text { 溜山油 vol\% } \\
\text { 合計 }\end{array}$ & 初溜點 $52.0^{\circ} \mathrm{C}$ (補正) \\
\hline$\sim 70$ & $3.0\} \sim 9.0$ & 乾 點 $170.5^{\circ} \mathrm{C}$ \\
\hline$\sim 80$ & $6.0\}^{\sim 9.0}$ & 總溜出量 $97.7 \%$ \\
\hline$\sim 90$ & $13.2 \sim 22.2$ & 殘油量 $0.9 \%$ \\
\hline$\sim 100$ & $16.6 \sim 38.8$ & 損失量 $1.4 \%$ \\
\hline$\sim 110$ & $17.8 \sim 56.6$ & 3)成分(vol\%) \\
\hline$\sim 120$ & $14.5 \sim 71.1$ & 牥香族炭化水素 $12.67 \%$ \\
\hline$\sim 130$ & $10.8 \sim 81.9$ & ナフテン族 " $32.38 \%$ \\
\hline$\sim 140$ & $7.5 \sim \varepsilon 9.4$ & パラフィン族” $54.95 \%$ \\
\hline $\begin{array}{l}\sim 150 \\
\sim 160\end{array}$ & $\begin{array}{l}4.5 \sim 93.9 \\
21 \sim 96.0\end{array}$ & 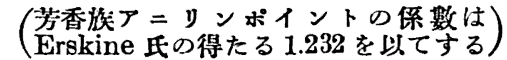 \\
\hline
\end{tabular}

（4）屈折㚖 $=1.4244$ (アッべ氏屈折計を用ひ $20^{\circ} \mathrm{C}$ に於て測定した) B. ペンゾール

(1) 比雷 $d_{4}^{15}=0.8764$ (前と问樣にして測定した)

（2）分溜成績 揮發油と㢄樣にして分溜した結果は次の如くであ る。

\begin{tabular}{|c|c|c|c|}
\hline $\begin{array}{l}\text { 溜 㟧 } \\
\text { 温度 }\end{array}$ & $\begin{array}{c}\text { 沼出油vol\% } \\
\text { 合計 }\end{array}$ & 乾 點 & $120^{\circ} \mathrm{C}$ \\
\hline$\sim 90$ & 67.8 & 總溜山I量 & $98.7 \%$ \\
\hline$\sim 100$ & $20.7 \sim 88.5$ & 殘油量 & $1.0 \%$ \\
\hline$\sim 110$ & $6.5 \sim 95.0$ & 損失鼔 & $0.3 \%$ \\
\hline
\end{tabular}

（3）屈折率 $=1.5010$ (前 と同㥞 にして测定した)

(4) 凝固默 $=-16^{\circ} \mathrm{C}$

C. アルコール

(1) 比重 $d_{4}^{15}=0.8153$

（2）酒精含量 $=95.13$ vol\%（但 し想性制を考虑せずにウインデッ シ二氏の酒精比重表より求めた）

（3）屈折率 $=1.3682$ (前と同樣に して测定した)

2. 裝置及測定法 ガソリン, ア ルコール, ヘンンデールを入れたる 3 本のビュレットを備へ試驗管の中へ先 づガッリンを滴下しコルク栓をして 秤量し, 次にアルコール, ペンジー ルの順に同樣にして秤取する。ガン リン,アルコール, ヘンゾールの容積

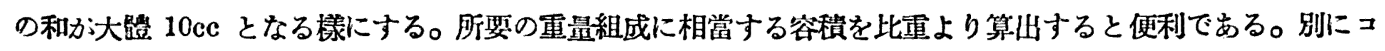
ルク栓に孔を開けて寒暖計を指迈み, 之を試料を入れた試稌管に插入して試驗管を密閉して測定中空中から水 分か吸收されない樣にする。冷却器としては 500cc 內容のビーカーを使用し之に適當の冷却劑を入れ, 試料を

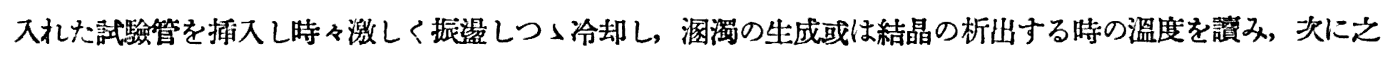

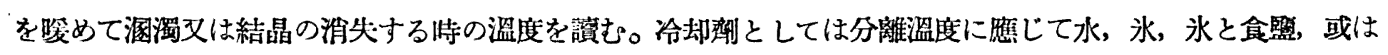

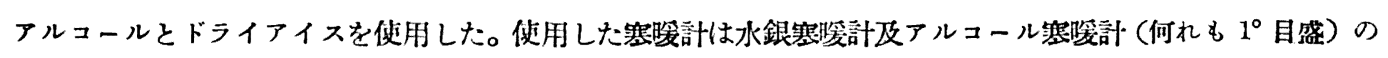
2 種で, 此を補正して補正值を加味して测定値を求めた。アルコール寒嗳計は + 20 - $76^{\circ}$ 目盛のるのを用ひ 
たので $+20^{\circ}$ 以上は水銀寒喛計を使用して湘定した。

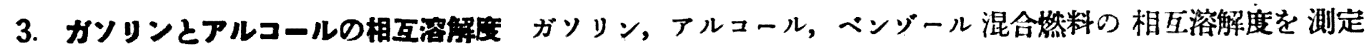

第 1 圆

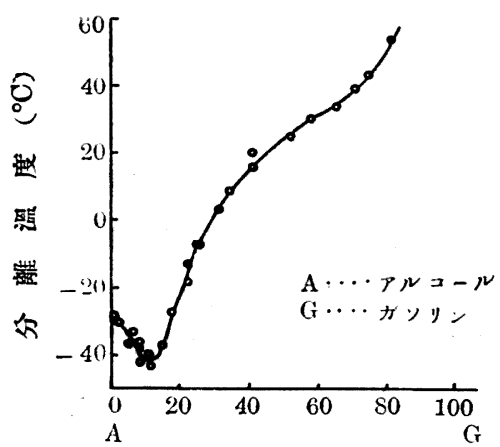

ガソリン及アルコールの\%(重量) するに當り先ゔガソッン, アルコール混合物の相互溶解度を湘定し た。郎ちガソリンとアルコールの混合物を 23 種類作製して其等の 臨界溶解溫度を湘定し，湘定値の 3 尼以上の壮均值を以て各配合物 の臨界溶解點とした。その結果を圖示すれば第 1 圆の如くなる。郎 ちガソリン, アルコール混合燃料の分離溫度は混合物中のガソリン が $10 \%$ 附近の時最低で，それから $30 \%$ 附近まで急激に上㫒し以 後ガソッンの量が增加するにつれて分㓠温度も漸次上昇の傾向を示 してるる。要するにガソッン,アルコール混合然料の分離溫度は混 合物中のアルュールの\%が畦加するに連れて降下するのである。而 してブリッヂマン氏 (交献前出) の測定結果も亦ガソリン,アルコー ル混合然料の臨界溶解溫度は混合物中のガソリンの量が減少するに

從て降トする事を示してるる。

4. アルコール, ヘンソール浴液の浴解度 第 1 圖に依り明白なる如くガソリン,アルコール混合燃料には 一定の溶解度があつて混合物中のアルコールの量が減少すれば分離溫度は著しく上舁する。此性質の䉆液體代 用燃料として該混合物を使用する際アルコールを少量混用すると其混合燃料は著しく不安定となる。此を防止 する篇にはガソリンとアルコールの相互溶解度を堛大せしむべく他物貿郎ち溶解促淮劑を添加する必要が生ず る。而して從來溶解促進劑としては芳香族炭化水素及高級アルコール類を添加する㸴究が行はれ，前者の中主 として考へられたのはベンジール及トルオールである。第 2 圖はアルュールとベンゾールの配合物を 37 種類

第 2 圖

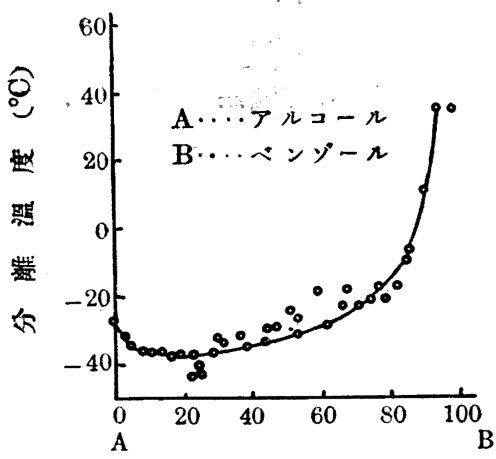

アルコール及ベンジールの\% (重是)

作軗して其等の臨界溶解溫度を测定した 結果を示したものである。アルコール,へ ンゾール混合液を冷却して或一定溫度に なると白色結晶が析出する場合が多く， 一度結晶が析出与ると温度が急激に上身

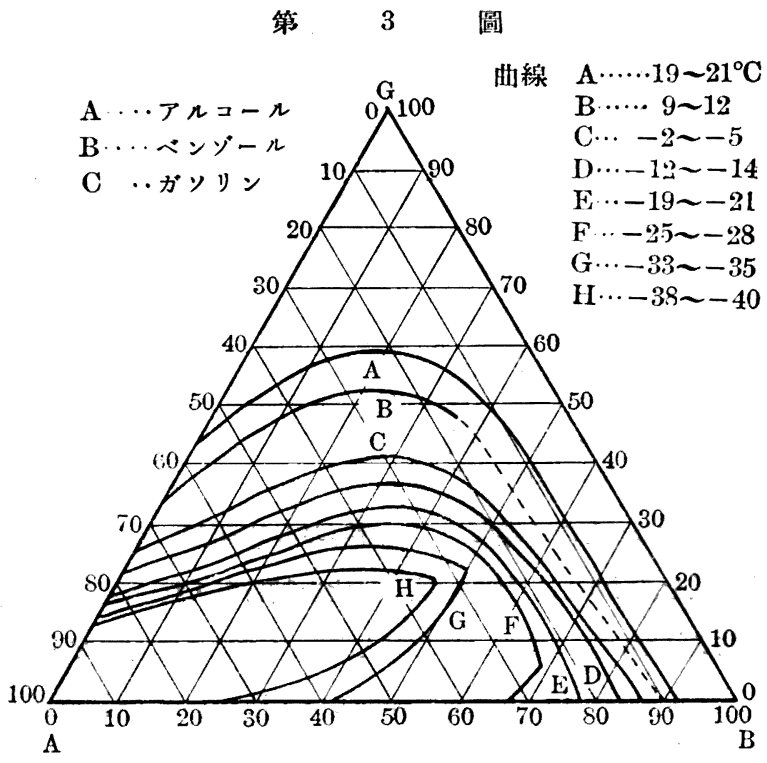

(重 勧 \%)

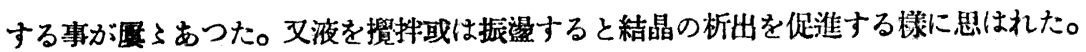


今第 2 圖をみるとアルコール, ヘンンジール混合液の分離溫度はベンゾール $20 \%$ 近邊を最低として以後漸次 上昇し， $80 \%$ 附近に至つて著しく上昇し $95 \%$ の熙に於て最高となる。又此を第 1 圖と比較するとアルコ一 ル，ヘンンゾール混合液の分離溫度はアルコール，ガッリン混合夜の分離溫度より低いことが知れる。

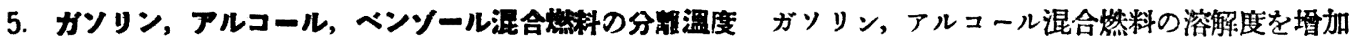
して分離溫度を降下させる篇ベンゾールを添加することは從來席く行はれてるる。ガッリン，アルコール，ヘ

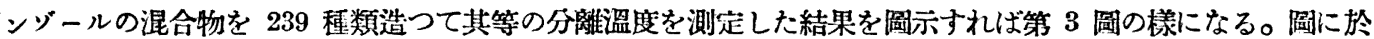

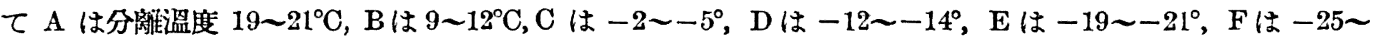
$-28^{\circ}, \mathrm{G}$ は $-33 \sim-35^{\circ}, 11$ は $-38 \sim-40^{\circ}$ を表はす曲線である。此等の諸曲線の中で曲線 $\mathrm{D}, \mathrm{E}, \mathrm{F}, \mathrm{G}, \mathrm{H}$ 等の 示ナ組成の混合㜣料は其等の分離溫度が $-12^{\circ} \mathrm{C}$ 以下であるから比較的安定である。

絬

錀

1. ガソリン，95\% アルコール混合液の分離溫度は混合液中の $95 \%$ アルュールの％が貸加するに連れて 降下し，アルュール 90\% 附近が極小である。

2. $95 \%$ アルコール, ベンゾール混合液の分離溫度はガソッン，95\% アルコール混合液の分灕溫度よりも低 い。アルコール，ベンゾール混合液中のベンゾールの\%が增加するに連れて分離溫度は上昇し $80 \%$ 以上に於 て急激に上昇する。

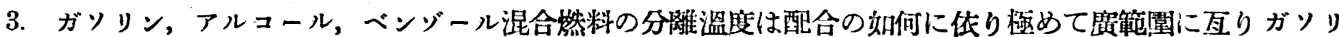
ンの量が多くアルュールの量が少い樣な配合物の分離溫度は高く，第 3 圆の曲線 D 以下 $\mathrm{E}, \mathrm{F}, \mathrm{G}, \mathrm{H}$ 等の曲 線に於ける各點は分離溫度 $-12 〜-14^{\circ} \mathrm{C}$ 以下なるため溶解性のみより考へる時は 寡用燃料となし得る可能性 がある。

4. 我々の目橪としてはガソリンを多量使用し酒情の量を少くしてアンチノッキングの性質を有する燃料油 を得たいので, 酒精 $20 \%$ 以內程度で臨界溶解默の低い混合物を得るため今後の望驗に於てこの種助劑の矽究 を進めんとするものである。

（東京帝國大學工學部應用化學科研究空）（昭和 9 年 1 月 10 日受理）

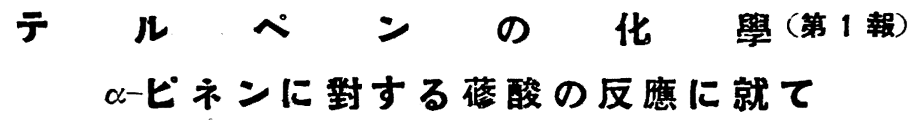

桑田角

$\alpha$ ーピネンを脫水媌酸と共に $140^{\circ} \mathrm{C}$ 附近に加熱すれば各種異性化並に重合テルペンと共に少量のボルネオー

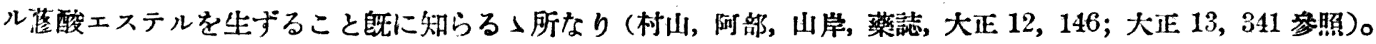

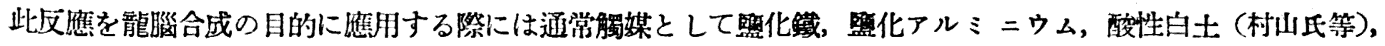
理酸ゲル又は珠酸ゲル明酸混合物 (田中芳雄氏及著者), 無水矹酸, メ夕硼酸等を存在せしめて $1 \mathrm{C} 0^{\circ} \mathrm{C}$ 以下の比 較的低溫に於て反應せしむ。是等の觸桇の伐用に依り龍腦の收率は理铪量の $50 \%$ 附近まで到至せしめ得れど も同時に㾞用上無價估に等しき重合テルベンの生成を避け難し。近年秋吉三郎氏（本誌，炤和 7, 35, 183C) は

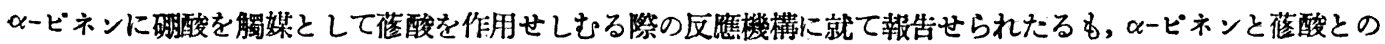
反應そのものに就て未だ不明なる點多し。妶に藷者は $\alpha$ ピネンと莑酸との直接反應に關する再吟味を企てたり。 